\title{
CONTRIBUIÇÃO PARA O CONTROLE DA QUALIDADE DE VACINAS INATIVADAS: ESTUDO DA DECOMPOSIÇÃO DA BETAPROPIOLACTONA EM DIFERENTES MEIOS.
}

Joyce Silva ${ }^{1}$; Kátia Leandroํ․

1 INCQS.

INTRODUÇÃO A vacina contra Febre Amarela utilizando o vírus atenuado apresenta um histórico de segurança e eficácia, no entanto os relatos esporádicos de eventos adversos em indivíduos sadios e a contra indicação da imunização em indivíduos imunocomprometidos, incentivam o desenvolvimento de pesquisas em prol de uma formulação utilizando o vírus inativado. Dentre as formas de inativação viral, a inativação química utilizando a betapropiolactona é a mais imunogênica. Para vacinas já disponíveis no mercado que utilizam esta forma de inativação órgãos internacionais especificam limtes residual abaixo de 25 nanogramas por $0,5 \mathrm{~mL}$, em função do potencial cancerígeno da BLP.

OBJETIVO Dessa forma, torna-se fundamental o desenvolvimento de metodologia analítica sensível para a detecção do residual da BPL na vacina contra a Febre Amerela.

METODOLOGIA No presente trabalho foram desenvolvidas metodologias utilizando a CGAR e CLAE com diferentes detectores e a escolha da metodologia mais adequada foi auxiliada pela espectroscopia de $\mathrm{RMN}$ de hidrogênio $\left({ }^{1} \mathrm{H}\right)$ e carbono $\left({ }^{13} \mathrm{C}\right)$. O método proposto para o estudo da BPL nas soluções virais em meio aquoso e tampão TRIS e HEPES foi a CLAE-UV em fase reversa, coluna C18, comprimento de onda $195 \mathrm{~nm}$ e fase móvel composta de solução de ácido fórmico 0,1\% pH 2,5: Acetonitrila (60:40).

RESULTADOS Em 105 minutos o residual de BPL em tampão HEPES foi indetectável e nos demais meios testados até 150 minutos ainda foi possível detectar sinal relativo à molécula. A BPL se decompôs em meio aquoso a $4^{\circ} \mathrm{C}$ seguindo um modelo de pseudo primeira ordem. Em meio aquoso a $20^{\circ} \mathrm{C}$ e em tampão TRIS, o decaimento ocorreu seguindo o modelo de pseudo segunda ordem. Em tampão HEPES as reações ocorreram rapidamente impossibilitando a determinação da cinética. A mudança nos 
modelos de decaimento para a BPL a $4^{\circ} \mathrm{C}$ e $20^{\circ} \mathrm{C}$ confirmou experimentalmente a grande influência que a temperatura exerce sobre as reações com BPL e a diferença observada no comportamento da molécula nos dois tampões estudados confirmou a que natureza dos nucleófilos modifica a estabilidade da molécula.

CONCLUSÃo Os resultados revelaram que o método proposto é promissor para uma avaliação semi quantitativa da BPL nas soluções virais, além de contribuir na investigação do comportamento da BPL na presença de nucleófilos. Para tal, o método ser otimizado e posteriormente validado a fim de disponibilizá-lo para uso na rotina do Controle da Qualidade da produção de uma vacina inativada contra o vírus da Febre Amarela de forma a garantir a segurança da vacina a ser oferecida a população.

PALAVRAS-CHAVE CLAE-UV, residual, betapropiolactona. 